\title{
FIRST DIRECT RADIOCARBON DATING OF THE LOWER CONGO ROCK ART (DEMOCRATIC REPUBLIC OF THE CONGO)
}

\author{
Geoffroy Heimlich ${ }^{1,2}$ • Pascale Richardin ${ }^{3}$ Nathalie Gandolfo ${ }^{3}$ Eric Laval ${ }^{3}$ - Michel Menu ${ }^{3}$
}

ABSTRACT. Lower Congo rock art is concentrated in a region that stretches from Kinshasa to the Atlantic coast and from northern Angola to southern Congo-Brazzaville. Although Lower Congo rock art was identified as early as the 19th century, it had never been a subject of thorough investigation. Presently inhabited by the Ndibu, one of the Kongo subgroups, the Lovo Massif is situated north of the ancient Kongo Kingdom. With 102 sites (including 16 decorated caves), the massif has the largest concentration of rock art in the entire region. In 2008 and 2010, we were able to collect pigment samples directly on the panels of the newly discovered decorated cave of Tovo. Unlike the Sahara and southern Africa, both extensively prospected, rock art of central Africa is still widely unknown and not dated. Radiocarbon dating of rock art in Africa is a real challenge and only a few direct dates have been obtained thus far. After verifying that the pigment samples were indeed charcoal, we proceeded to ${ }^{14} \mathrm{C}$ date them using accelerator mass spectrometry (AMS). The results indicate dates between cal AD 1480 and 1800, confirming that the occupation of Tovo Cave was contemporaneous with the ancient Kongo Kingdom.

\section{INTRODUCTION}

The rock art of Lower Congo, the westernmost region of the present-day Democratic Republic of the Congo, is concentrated in a region that stretches from Kinshasa to the Atlantic coast and from northern Angola to southern Congo-Brazzaville (de Maret 1982). In central Africa, the Lower Congo possesses one of the richest concentrations of rock art with 145 inventoried sites (Figure 1). Although Lower Congo rock art was identified as early as the 19th century by James Tuckey in the course of his exploration of the Congo River (Tuckey 1818), it had never been the subject of thorough investigation. Its historic period still remains uncertain.

This preliminary research revealed one coherent entity: the Lovo Massif, today inhabited by the Ndibu, one of the Kongo subgroups. The massif is situated north of the ancient Kongo Kingdom (Boone 1973). When Portuguese sailors discovered this kingdom in 1483, they were amazed to find a centralized political state. At the height of the Kongo hegemony, during the second half of the 16th and the first half of the 17th century, the Kongo Kingdom extended over the territory of the modern nations of the Democratic Republic of the Congo, Angola, and Congo-Brazzaville, an area of about $130,000 \mathrm{~km}^{2}$ (Thornton 1977, 1983). Following the conversion to Christianity of several kings beginning in the 15th century, missionaries, emissaries, and traders were able to provide a precise description of the daily and religious life of the kingdom. After 1500, it is one of the best-documented kingdoms from all Africa, historically (Cuvelier and Jadin 1954; Balandier 1965; Vansina 1965; Randles 1968; Thornton 1983; Hilton 1985) as well as ethnographically and at the same time anthropologically for more recent periods (Van Wing 1959; Fu-Kiau kia Bunseki-Lumanisa 1969; Janzen and MacGaffey 1974; Thompson et al. 1981; MacGaffey 1986; Janzen 1995; de Heusch 2000). However, the kingdom remains almost unknown from an archaeological point of view (Clist 1991, 2012; de Maret 2002, 2005, 2006). Systematic archaeological research on the origins of the kingdom has never been conducted (Vansina 1963, 1994; Denbow 1990, 2012; Thornton 2001; de Maret 2005). The archaeological research done in the Lower Congo region so far shows a high density of prehistoric inhabited sites and the presence of sedentary populations with pottery, polished stones, and probably villages around 500 BC (de Maret 1986). There is a gap in the archaeological

${ }^{1}$ CEMAf, Centre d’Etudes des Mondes Africains, Université de Paris I Panthéon-Sorbonne, Paris 75004, France.

${ }^{2} \mathrm{CReA}$ - Patrimoine, Centre de Recherches en Archéologie et Patrimoine, Université Libre de Bruxelles, Bruxelles 1050, Belgium. Corresponding author. Email: geoffroy.heimlich@ulb.ac.be.

${ }^{3}$ C2RMF, Centre de Recherche et de Restauration des Musées de France, Palais du Louvre, Paris 75001, France.

C 2013 by the Arizona Board of Regents on behalf of the University of Arizona

Proceedings of the 21st International Radiocarbon Conference edited by A J T Jull \& C Hatté

RADIOCARBON, Vol 55, Nr 2-3, 2013, p 1383-1390 


\section{G Heimlich et al.}

records between $\mathrm{AD} 250$ and 1000. After that date, several ceramic traditions related to the kingdom have been found again. Their scattering suggests complex trade networks (de Maret 2005).

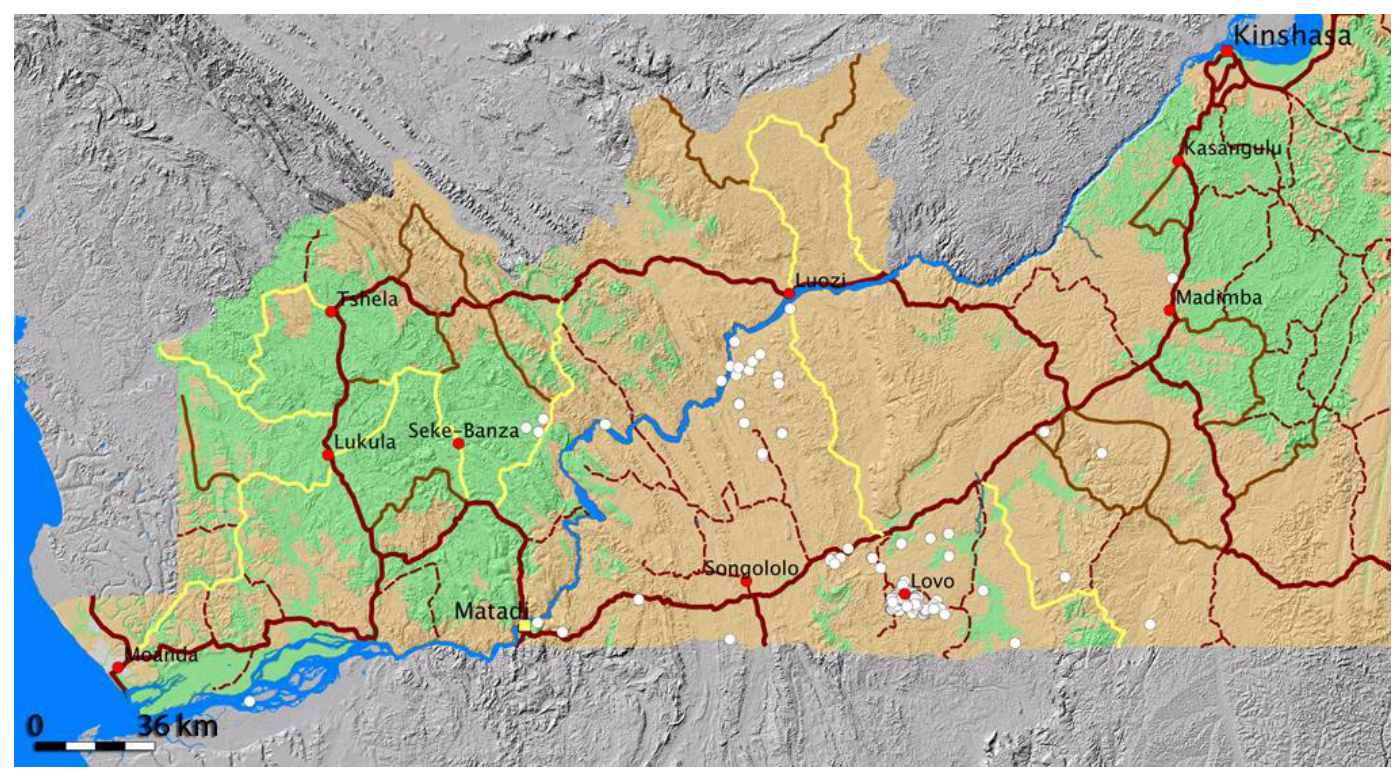

Figure 1 Map of Lower Congo showing the distribution of rock-art sites

\section{SITE DESCRIPTION}

With 102 sites (including 16 decorated caves), the Lovo Massif is the largest concentration of rock art in the entire region. Hundreds of limestone outcrops with carved surfaces, punctuated by numerous caves and rockshelters, rise up over an area of about $400 \mathrm{~km}^{2}$. The Lovo Massif is also located on an ancient caravan route and close to iron deposits (Commission de géologie du Ministère des Colonies 1958). During our fieldwork, we were able to study 57 rock-art sites, 50 of which had not been documented before, with more than 5000 rock images in total (Heimlich 2010a,b). The inventory comprises mostly geometric drawings $(83.4 \%)$ that can be related to anthropomorphs $(7.1 \%)$ and zoomorphs $(6.1 \%)$. There are also a very few therianthropes $(0.3 \%)$, alphabetical inscriptions $(2.6 \%)$, and positive hands $(0.2 \%)$. Direct radiocarbon dating of pigment samples from the unexplored cave of Tovo shed light on the chronology of the Lower Congo rock art and the interpretation of the cross motif.

\section{EXPERIMENTAL}

\section{Samples}

Tovo Cave crosses the top of an outcrop from one side to the other. The designs are located in the first room, where they are largely obliterated, and in the upper gallery, where access is very difficult. In this gallery, geometric drawings are dominant, in contrast to the first room with lizards and anthropomorphic shapes. In 2008 and 2010, 6 black pigment samples were collected from the upper gallery.

A first pigment sample (T1) was taken from a rectangular grid drawing on the edge of the gallery. At the base of the decorated wall, a large charcoal fragment (T50) was collected. Two other pigment samples $(\mathrm{T} 3, \mathrm{~T} 8)$ were also sampled from 2 geometric drawings at the bottom of this gallery. The 
last 3 samples (T4, T5, T6) were taken from the third panel (Figure 2) in a confined room from the upper gallery, only accessible by a narrow passage. Two crosses made of 2 lines intersecting at their center are associated with an unidentified drawing (a coat of arms?). The same type of cruciform motif is also found in the first room, but not clearly associated with any particular drawing. At the base of the decorated wall, we also found a hearth and nearby charcoal (T2), of which traceological study showed some characteristics of pencilling.
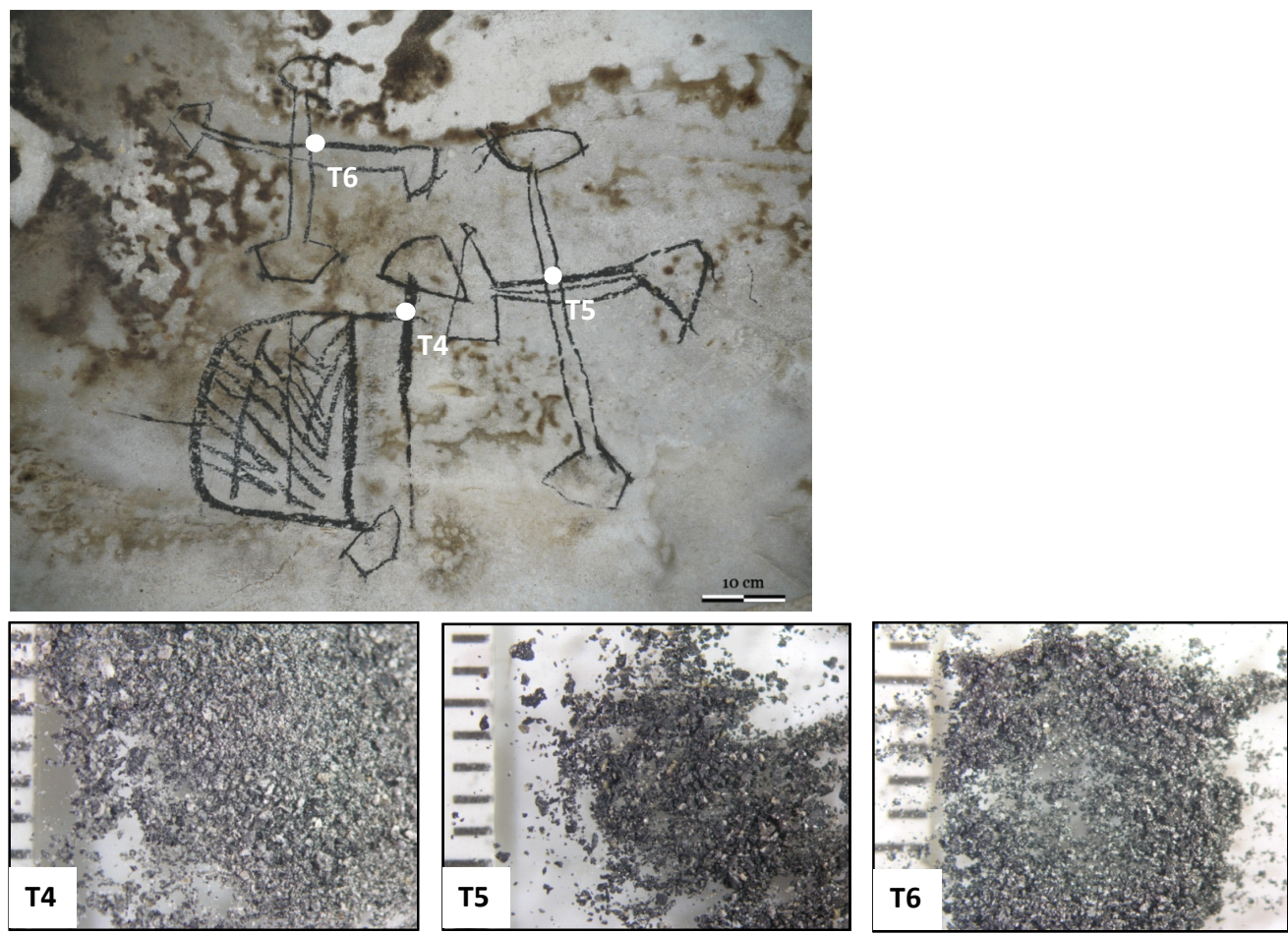

Figure 2 Localization and binocular observation of the samples T4, T5, and T6 collected from panel 3

\section{Scanning Electron Microscopy with Energy Dispersive X-Ray Analysis (SEM-EDX)}

The apparatus used to analyze the samples is a Phillips XP CL 30 series, coupled with an energy dispersive X-ray spectrometer. The accelerating voltage was set to $20 \mathrm{kV}$ at low pressure $\left(4 \times 10^{-6} \mathrm{bar}\right)$. In order to have usable results, we put the samples in a small cup of pure nickel, which does not interfere with the analysis because it does not fit in the elemental composition of ancient paintings. The advantage of this protocol is that it allows us to preserve the sample in its entirety and thus to consider later other types of analyses.

\section{Radiocarbon Dating}

After sorting the charcoal fragments under binocular microscope and washing with ultrapure water, samples were prepared following the classical acid-alkali-acid (AAA) protocol previously described (Richardin et al. 2010). First, samples are treated with a $0.5 \mathrm{~N} \mathrm{HCl}$ solution (VWR International, used as received) for $1 \mathrm{hr}$ at $80^{\circ} \mathrm{C}$. After rinsing the residue with warm water, and adding water until neutral, a similar treatment is conducted with a fresh $\mathrm{NaOH} 0.05 \mathrm{~N}$ aqueous solution (prepared from a sodium hydroxide solution at $0.1 \mathrm{~N}$ from VWR International), followed by another rinsing with 


\section{G Heimlich et al.}

ultrapure water. A last acidic treatment (similar to the first one) is done. The clean samples were allowed to dry overnight in a low-vacuum $(100 \mathrm{mbar})$ oven at $60^{\circ} \mathrm{C}$. During the sample preparation, the extraction of exogenous organic matter is checked by binocular observation.

The dried organic fraction is then combusted at high temperature $\left(5 \mathrm{hr}\right.$ at $\left.850{ }^{\circ} \mathrm{C}\right)$ under high vacuum $\left(10^{-6}\right.$ Torr). Some 2 to $2.5 \mathrm{mg}$ of pretreated sample are combusted in a quartz tube with $500 \mathrm{mg} \mathrm{CuO}$ (CuII oxide on $\mathrm{CuI}$ oxide heart for analysis, VWR International) and Ag wire (99.95\%, Aldrich). The combustion gas is separated by cryogenic purification and the $\mathrm{CO}_{2}$ is collected in a sealed tube. The graphitization is achieved by direct catalytic reduction of the $\mathrm{CO}_{2}$ with hydrogen, using Fe powder at $600{ }^{\circ} \mathrm{C}$ and an excess of $\mathrm{H}_{2}$. During the process, the carbon is deposited on the iron and the whole powder is mechanically pressed into a flat pellet.

All measurements were conducted by the Artemis AMS facility of Saclay (France) (Cottereau et al. 2007). ${ }^{14} \mathrm{C}$ ages are calculated with correcting the isotope fractionation $\delta^{13} \mathrm{C}$, calculated from AMS measurements of the ${ }^{13} \mathrm{C} /{ }^{12} \mathrm{C}$ ratio. Calendar ages are determined using OxCal v 4.2 (Bronk Ramsey 2009) and the terrestrial calibration curve SHCal04 (McCormac et al. 2004). Calibrated age ranges correspond to $95.4 \%$ probability $(2 \sigma)$ and are expressed in years cal BC or cal AD.

\section{RESULTS}

The observation of the pigments by SEM (Figure 3) shows that the drawings were made with charcoal (Menu et al. 1993; Tomasini et al. 2012) and it is therefore possible to date the material by ${ }^{14} \mathrm{C}$. Thus, for the first time direct dates from Lower Congo rock art were achieved. The results obtained on the charcoal samples indicate dates from cal AD 1480 to 1800 (Table 1). The T1 sample gives a date between cal AD 1621 and 1677. Sample T8 dated between cal AD 1487 and 1642, and T3 dated to cal AD 1478-1639. For panel 3, the cross on the left was dated to cal AD 1729-1804 (T6) with an almost identical age of cal AD 1730-1803 for the cross on the right (T5).

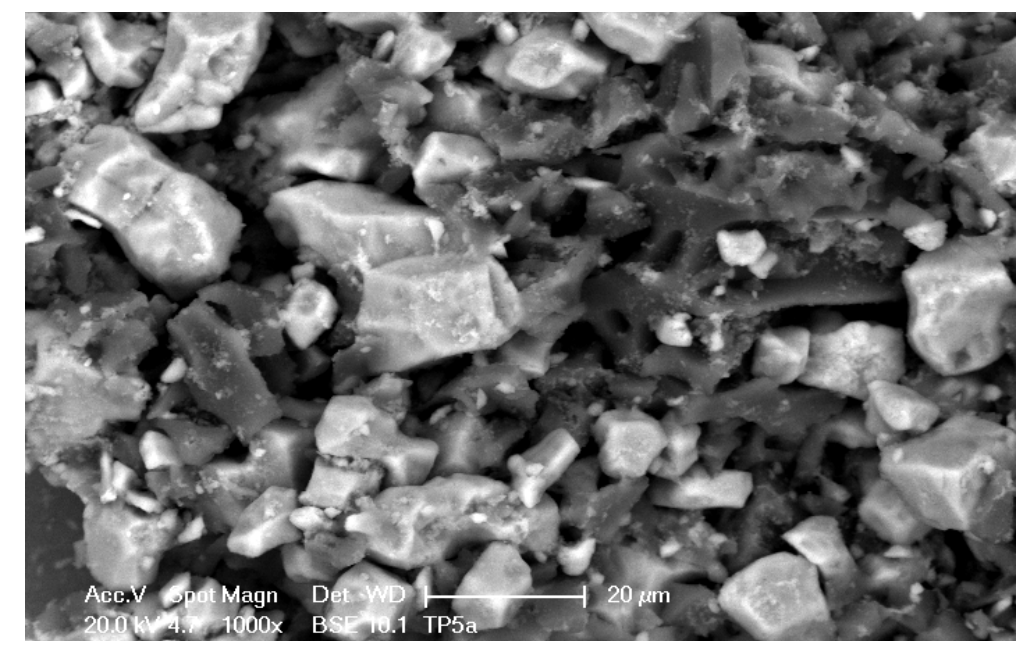

Figure 3 SEM image (BSE) of sample T5, showing the charcoal structure

A careful study of the decorated wall revealed a very localized undetermined substance (with a soft texture and a reddish color). Examination using a binocular microscope shows that these same red crystals seem to be associated with the charcoal pigment of the unidentified drawing (Figure 4). This drawing (T4) has been dated to cal AD 1625-1679. 
${ }^{14} \mathrm{C}$ Dating of the Lower Congo Rock Art

Table 1 Radiocarbon ages (yr BP) and calibrated ages for the samples.

\begin{tabular}{|c|c|c|c|c|}
\hline $\begin{array}{l}\text { Nature and origin } \\
\text { of the sample }\end{array}$ & $\begin{array}{l}\text { Sample } \\
\text { reference }\end{array}$ & Lab code & $\begin{array}{l}{ }^{14} \mathrm{C} \text { age } \\
\text { (yr BP) }\end{array}$ & Calibrated age $(2 \sigma)$ \\
\hline \multirow{2}{*}{$\begin{array}{l}\text { Charcoal - on the floor, } \\
\text { under the painted panels }\end{array}$} & $\mathrm{T} 2$ & SacA-18832 & $350 \pm 30$ & AD $1490(95.4 \%) 1645$ \\
\hline & $\mathrm{T} 50$ & SacA-17788 & $245 \pm 30$ & $\begin{array}{l}\text { AD } 1638(34.1 \%) 1687 \\
\text { AD } 1728(61.3 \%) 1804\end{array}$ \\
\hline \multirow[t]{7}{*}{ Charcoal - painting } & $\mathrm{T} 1$ & SacA-21461 & $280 \pm 30$ & $\begin{array}{l}\text { AD } 1511(12.1 \%) 1574 \\
\text { AD } 1621(57.1 \%) 1677 \\
\text { AD } 1736(26.2 \%) 1800\end{array}$ \\
\hline & $\mathrm{T} 3$ & SacA-21462 & $355 \pm 30$ & AD $1487(95.4 \%) 1642$ \\
\hline & $\mathrm{T} 3$ & SacA-21463 & $325 \pm 30$ & $\begin{array}{l}\text { AD } 1499(65.3 \%) 1599 \\
\text { AD } 1609(30.1 \%) 1655\end{array}$ \\
\hline & $\mathrm{T} 4$ & SacA-22300 & $270 \pm 30$ & 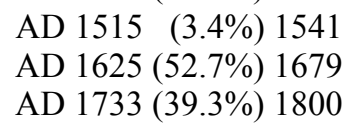 \\
\hline & $\mathrm{T} 5$ & SacA-22301 & $255 \pm 30$ & $\begin{array}{l}\text { AD } 1633(40.7 \%) 1682 \\
\text { AD } 1730(54.7 \%) 1803\end{array}$ \\
\hline & T6 & SacA-22302 & $250 \pm 30$ & $\begin{array}{l}\text { AD } 1636(37.1 \%) 1684 \\
\text { AD } 1729(58.3 \%) 1804\end{array}$ \\
\hline & $\mathrm{T} 8$ & SacA-22303 & $365 \pm 30$ & AD $1478(95.4 \%) 1639$ \\
\hline
\end{tabular}

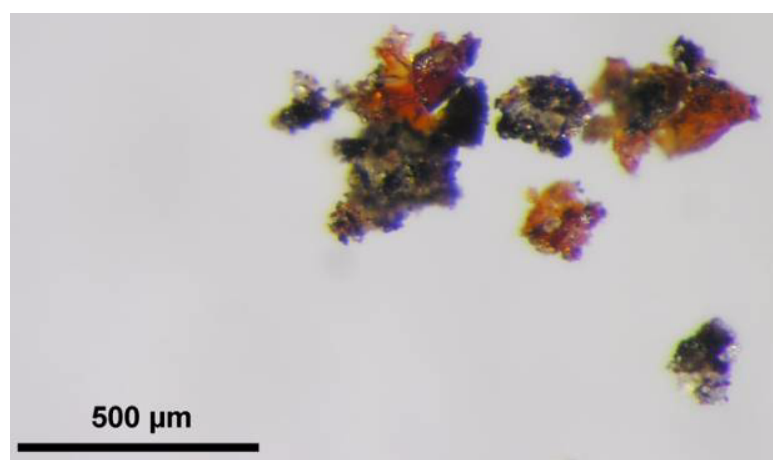

Figure 4 Binocular observation of sample T4

\section{DISCUSSION}

Could rock art be connected with the kimpasi, the great religious initiation ritual? Reported in the second half of the 17th century by Fathers Girolamo da Montesarchio and Giovanni Antonio Cavazzi, the kimpasi took place south of the Congo River and experienced a large geographical extension in the 17th century (Cavazzi de Montecuccolo 1687; de Bouveignes and Cuvelier 1951). This initiation happens whenever the community feels the need to grow stronger to remedy diseases that plague it (Thornton 1983). A pinnacle of resistance to Christianity, it was seen by early missionaries as a major obstacle to their action. Father Cavazzi (1687) describes an enclosure forbidden to the uninitiated, called "Wall of the King of Congo," where the "Nequiti" engage in secret rites "in the most remote places." The central, defining rite of the kimpasi was the initiation ceremony that staged the symbolic death and resurrection of the candidate in the sacred enclosure. 


\section{G Heimlich et al.}

During the 17th and 18th centuries, missionaries often noted that, in the Kongo worldview, the motif of the cross was closely linked to the cyclic passage from death to an afterlife. Closely associated with the kimpasi, the cross was used to mark the entrance to the initiation enclosure (de Bouveignes and Cuvelier 1951) or to reinforce the power of an "idol," during ceremonies (Cavazzi de Montecuccolo 1687). In contrast to the Latin cross, in which lines meet three-quarters up the long segment, Cecile Fromont defines the "Kongo cross" as "the intersection of two lines in their middle" (Fromont 2008, 2009), as seen in the cave art of Tovo.

Oral traditions collected in the Lovo Massif could confirm this hypothesis. Local chiefs of Kuluzu dia Lovo and Nkula 2, Pierre Constant Makumbu and Ndongala Menankuntima, say that 2 outcrops are still known for hosting kimpasi until the early 20th century. Tadi dia Kimpasi and Mongo dia Ngiandilwa are both located close to Tovo Cave. Below Mongo dia Ngiandilwa is situated the ancient village of Mbanza Mbota and its cemetery. We were able to discover there 3 new rock-art sites. The rock images are similar to those of Tovo Cave, notably the "kongo cross" (Figure 5).

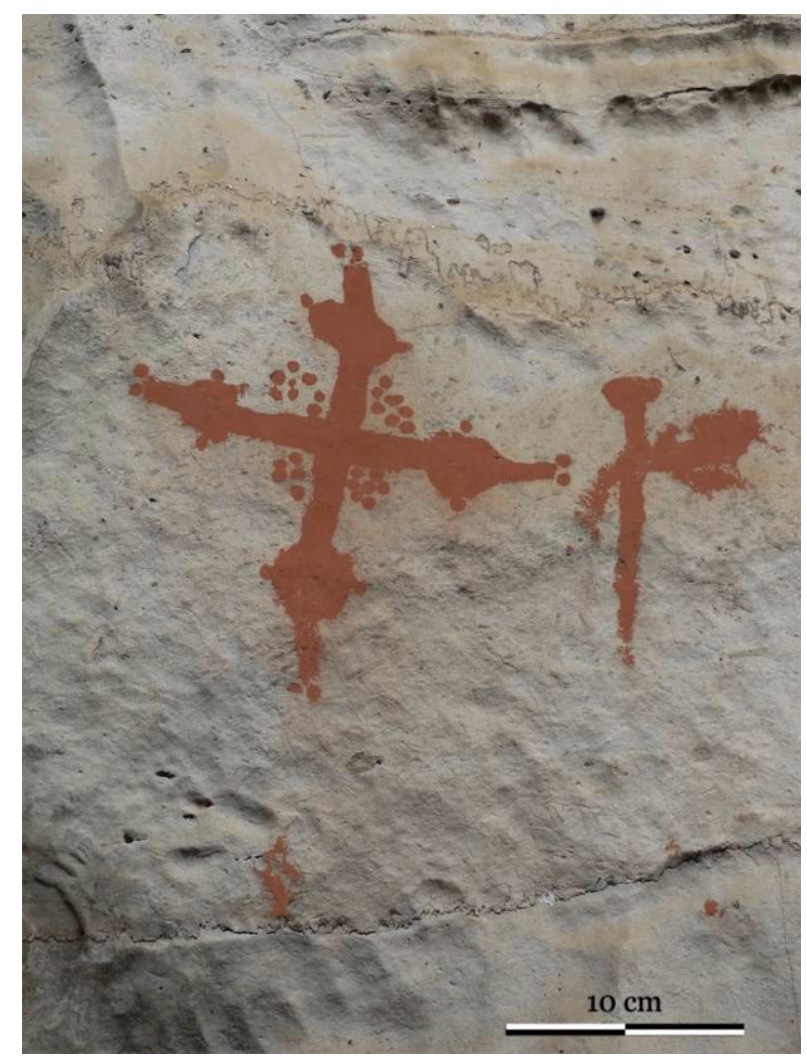

Figure 5 Example of "Kongo cross" at the rock-art site of Mbanza Mbota

Considered as an historical document, the Lower Congo rock art is guided by a consistent practice and rules of apprenticeship, related to graphic expression as well as oral learning. In the case of Tovo Cave, some of the rock art could be connected with the kimpasi initiation. 
${ }^{14} \mathrm{C}$ Dating of the Lower Congo Rock Art

\section{CONCLUSION}

These preliminary results indicate for Tovo Cave dates between cal AD 1480 and 1800, thus confirming an occupation contemporaneous with the ancient Kongo Kingdom. However, the possibility that leftover material from prior cave occupation has been used cannot be excluded either and must be taken into account (Valladas 2003; Cuzange et al. 2007). Nevertheless, it should also be noted that the dates obtained for the Kongo crosses are not surprising, knowing that this design is similar to many objects of Kongo Christian art like crucifixes or tombstones from the same period.

In order to verify the chronological framework of these images, more direct dates from paintings must be obtained, especially since it is quite possible that this rock art could well have started earlier. In 2011, new samples of charcoal pigments were collected in the first room of the Tovo and in the unpublished decorated cave of Nkamba, where a nkisi was discovered hidden in the wall. A nkisi is "a material composite through which a spirit can be approached" (MacGaffey et al. 1993). These results will be published soon.

\section{ACKNOWLEDGMENTS}

Our 4 archaeological field studies were undertaken in Lower Congo, from 2007 to 2011, by Geoffroy Heimlich as part of his doctoral work, under the supervision of Pierre de Maret and Jean-Loïc Le Quellec. Field research for this project was made possible by logistical support from the Compagnie Sucrière at Kwilu-Ngongo. We received financial assistance from the French Institute of South Africa (IFAS). Our fieldwork was undertaken with the support of, and in close collaboration with, the Institute of the National Museums of Congo, the Center for Research and Restoration of the Museums of France (C2RMF), the Royal Museum for Central Africa, as well as the UNESCO Center for the World Heritage and the UNESCO office in Kinshasa. We thank all those who assisted us from these institutions. In the field, our heartiest thanks go to Clément Mambu Nsangathi of the Institute of the National Museums of Congo. We must express special gratitude to the people of the Lovo, Nkula, and Mbanza Nkula villages. We thank also Christophe Moreau and his team from the Laboratory of Measurement of Carbon 14 (LMC14 - UMS2572) for the ${ }^{14} \mathrm{C}$ measurements.

\section{REFERENCES}

Balandier G. 1965. La vie quotidienne au royaume de Kongo du XVIe au XVIII siècle. Paris: Hachette.

Boone O. 1973. Carte ethnique de la République du Zaïre. Quart sud-ouest. Tervuren: Musée royal de l'Afrique centrale.

Bronk Ramsey C. 2009. Bayesian analysis of radiocarbon dates. Radiocarbon 51(1):337-60.

Cavazzi de Montecuccolo GA. 1687. Istorica descrizione de' tre regni Congo, Matamba ed Angola sitvati nell' Etiopia inferiore occidentale e delle missioni apostoliche esercitateui da religiosi Capuccini. Bologna: Giacomo Monti. 784 p.

Clist B. 1991. L'Archéologie du Royaume de Kongo. In: Lanfranchi R, Clist B. Aux origines de l'Afrique centrale. Libreville: Centre culturel français de Libreville, CICIBA. p 253-6.

Clist B. 2012. Pour une archéologie du royaume Kongo: la tradition de Mbafu. Azania: Archaeological Research in Africa 47(2):175-209.

Commission de géologie du Ministère des Colonies.
1958. Carte géologique du Congo belge et RuandaUrundi: Feuille Thysville S. 6/ 14.

Cottereau E, Arnold M, Moreau C, Baqué D, Bavay D, Caffy I, Comby C, Dumoulin J-P, Hain S, Perron M, Salomon J, Setti V. 2007. Artemis, the new ${ }^{14} \mathrm{C}$ AMS at LMC14 in Saclay, France. Radiocarbon 49(2):2919.

Cuvelier J, Jadin L. 1954. L'ancien Congo d'après les archives romaines, 1518-1640. Brussels: Académie Royale des Sciences Coloniales.

Cuzange M-T, Delqué-Količ E, Goslar T, Grootes PM, Higham T, Kaltenecker E, Nadeau M-J, Oberlin C, Paterne M, van der Plicht J, Bronk Ramsey C, Valladas H, Clottes J, Geneste J-M. 2007. Radiocarbon intercomparison program for Chauvet Cave. Radiocarbon 49(2):339-47.

de Bouveignes O, Cuvelier J. 1951. Jérôme de Montesarchio, Apôtre du Vieux Congo. Namur: Grands Lacs.

de Heusch L. 2000. Le roi de Kongo et les monstres sacrés, Mythes et rites bantous III. Paris: Gallimard. 


\section{G Heimlich et al.}

de Maret P. 1972. Etude d'une collection de céramiques protohistoriques du Bas-Zaïre. Mémoire de Licence. Brussels: Université Libre de Bruxelles.

de Maret P. 1982. Rock art. In: Van Noten F. The Archaeology of Central Africa. Graz: Akademische Drück- u. Verlagsanstalt. p 97-9.

de Maret P. 1986. The Ngovo Group: an industry with polished stone tools and pottery in Lower Zaïre. The African Archaeological Review 4:103-33.

de Maret P. 2002. Urban origins in Central Africa: the case of Kongo. In: Sinclair P. The Development of Urbanism in Africa from a Global Perspective. Uppsala: Uppsala Universiteit, Institutionen för arkeologi och antik historia, Afrikansk och jämförande arkeologi.

De Maret P. 2005. From pottery groups to ethnic groups in Central Africa. In: Stahl AB, editor. African Archaeology: A Critical Introduction. Oxford: Blackwell. p 420-40.

de Maret P. 2006. What to expect in excavating the Kongo Kingdom capital. In: Wotzka HP, editor. Grundlegungen. Beiträge zur europäischen und afrikanischen Archäologie für Manfred K.H. Eggert. Tübingen: Francke. p 319-28.

Denbow J. 1990. Congo to Kalahari: data and hypotheses about the political economy of the western stream of the Early Iron Age. African Archaeological Review 8: 139-76.

Denbow J. 2012. Pride, prejudice, plunder, and preservation: archaeology and the re-envisioning of ethnogenesis on the Loango coast of the Republic of Congo. Antiquity 86(332):383-408.

Fromont C. 2008. Under the sign of the cross in the Kingdom of Kongo: shaping images and molding faith in early modern central Africa [unpublished PhD dissertation]. Cambridge: Harvard University.

Fromont C. 2009. Icônes chrétiennes ou symboles kongo? L'art et la religion en Afrique centrale au temps de la Traite, XVII $-\mathrm{XVIII}$ siècles. Les Cahiers des Anneaux de la Mémoire 12:47-60.

Fu-Kiau kia Bunseki-Lumanisa A. 1969. Le Mukongo et le monde qui l'entourait (N'Kongo ye nza yakun'zungidila: nza-Kôngo). Kinshasa: Office National de la Recherche et du Développement.

Heimlich G. 2010a. Un archéologue au Congo [Web documentary produced with Le Monde.fr and ARTE Radio.com.] URL: http://www.lemonde.fr/congo. Accessed August 2012.

Heimlich G. 2010b. Lower Congo rock art revisited. Nyame Akuma 74:42-50.

Hilton A. 1985. The Kingdom of Kongo. Oxford: Oxford University Press.

Janzen JM. 1995. La quête de la thérapie au Bas-Zaïre. Paris: éditions Karthala.

Janzen JM, MacGaffey W. 1974. An Anthology of Kongo Religion: Primary Texts from Lower Zaïre. Lawrence: University of Kansas Press.
MacGaffey W. 1986. Religion and Society in Central Africa: The BaKongo of Lower Zaire. Chicago: University of Chicago Press.

MacGaffey W, Harris M, Williams S, Driskell D, National Museum of African Art (US). 1993. Astonishment and Power. Washington, DC: Smithsonian Institution Press.

McCormac FG, Hogg AG, Blackwell PG, Buck CE, Higham TFG, Reimer PJ. 2004. SHCal04 Southern Hemisphere calibration 0-11.0 cal kyr BP. Radiocarbon 46(3):1087-92.

Menu M, Walter P, Vigears D, Clottes J. 1993. Façons de peindre au Magdalénien. Bulletin de la Société préhistorique française 90:426-32.

Randles WGL. 1968. L'ancien royaume du Congo des origines à la fin du XIXe siècle. Paris: Mouton \& co.

Richardin P, Cuisance F, Buisson N, Asensi-Amoros V, Lavier C. 2010. AMS radiocarbon dating and scientific examination of high historical value manuscripts: application to two Chinese manuscripts from Dunhuang. Journal of Cultural Heritage 11(4):398-403.

Thompson RF, Cornet J, National Gallery of Art (US). 1981. The Four Moments of the Sun: Kongo Art in Two Worlds. Washington, DC: National Gallery of Art.

Thornton J. 1977. Demography and history in the Kingdom of Kongo, 1550-1750. The Journal of African History 18(4):507-30.

Thornton J. 1983. The Kingdom of Kongo: Civil War and Transition, 1641-1718. Madison: University of Wisconsin Press.

Thornton J. 2001. The origins and early history of the Kingdom of Kongo, c. 1350-1550. The International Journal of African Historical Studies 34(1):89-120.

Tomasini E, Siracusano G, Maier MS. 2012. Spectroscopic, morphological and chemical characterization of historic pigments based on carbon, paths for the identification of an artistic pigment. Microchemical Journal 102:28-37.

Tuckey JK. 1818. Narrative of an Expedition to Explore the River Zaire, Usually Called the Congo, in South Africa, in 1816. London: John Murray.

Valladas H. 2003. Direct radiocarbon dating of prehistoric cave paintings by accelerator mass spectrometry. Measurement Science and Technology 14(9):148792.

Vansina J. 1963. Notes sur l'Origine du Royaume de Kongo. The Journal of African History 4(1):33-8.

Vansina J. 1965. Les anciens royaumes de la savane. Les états des savanes méridionales de l'Afrique centrale des origines à l'occupation coloniale. Léopoldville: Institut de recherches économiques et sociales.

Vansina J. 1994. Antécédents des royaumes Kongo et Teke. Muntu 9:7-49.

Van Wing J. 1959. Etudes Bakongo; sociologie, religion et magie. Bruges: Desclée De Brouwer. 